\title{
Evaluation of different monitoring methods of surface cleanliness in operating rooms
}

\author{
Avaliação dos diferentes métodos de monitoramento de limpeza de superfície em sala operatória \\ Evaluación de diferentes métodos de monitoreo de limpieza de superficie en sala operatoria
}

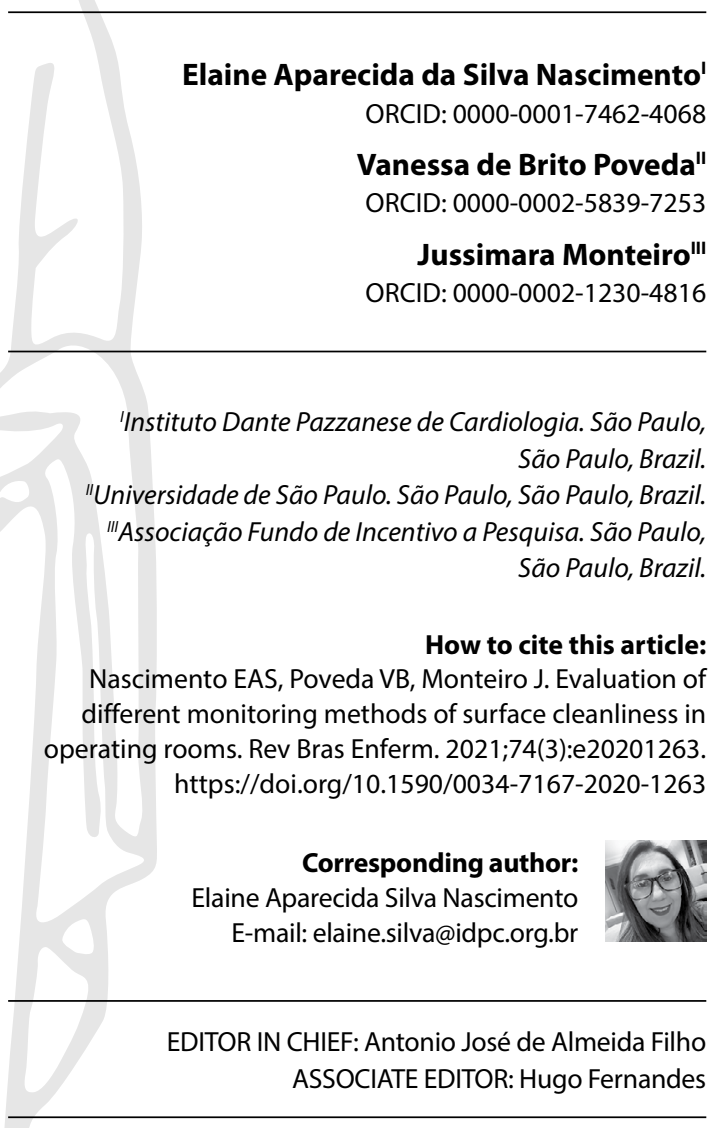

Submission: 12-18-2020

Approval: 02-07-2021

\begin{abstract}
Objectives: to evaluate different monitoring methods for detecting the presence of organic or biological matter before and after the cleaning and disinfection processes of the operating room. Methods: this is a cross-sectional study based on visual inspection, adenosine triphosphate levels and microbiological culture for the assessment of cleaning and disinfection. Results: $93.3 \%$ of the surfaces inspected visually for this study purpose were considered clean, even when high levels of adenosine triphosphate and microbiological analysis detected presence of microorganisms relevant to biofilm formation. Conclusions: the cleaning and disinfection processes reduced the microbial load and organic matter of the inspected surfaces, demonstrated by the values obtained by the adenosine triphosphate bioluminescence assay and microbiological analysis, but the visual inspection as a unique tool to assess the surfaces' cleanliness may give a false impression of clean environment. Descriptors: Nursing; Operating Rooms; Cleaning; Disinfection; Contamination.
\end{abstract}

\section{RESUMO}

Objetivos: avaliar diferentes métodos de monitoramento da presença de matéria orgânica ou biológica entre a limpeza e a desinfecção da sala cirúrgica. Métodos: trata-se de um estudo transversal utilizando a inspeção visual, amostras de trifosfato de adenosina e cultura microbiológica como indicadores para avaliação da limpeza e a desinfecção. Resultados: 93,3\% das áreas avaliadas visualmente neste estudo apresentavam-se visualmente limpas, mesmo na presença de altos níveis de bioluminescência no resultado de trifosfato de adenosina e análises microbiológicas detectando a presença de microrganismos relevantes para a formação de biofilmes. Conclusões: o processo de limpeza e desinfecção reduziu a carga microbiana e matéria orgânica das superfícies avaliadas, demonstrada pelos resultados obtidos pelo trifosfato de adenosina e avaliação microbiológica, mas a inspeção visual como ferramenta única para avaliar a eficácia da limpeza das superfícies, pode gerar uma falsa impressão de ambiente limpo. Descritores: Enfermagem; Salas de Cirurgia; Limpeza; Desinfecção; Contaminação.

\section{RESUMEN}

Objetivos: evaluar diferentes métodos de monitoreo de la presencia de materia orgánica o biológica entre la limpieza y desinfección de la sala quirúrgica. Métodos: estudio transversal utilizando la inspección visual, muestras de adenosina trifosfato y cultura microbiológica como indicadores para evaluación de la limpieza y desinfección. Resultados: 93,3\% de las áreas evaluadas visualmente en este estudio se presentaban visualmente limpias, mismo en la presencia de altos niveles de bioluminiscencia en el resultado de adenosina trifosfato y análisis microbiológicos detectando la presencia de microorganismos relevantes para la formación de biofilms. Conclusiones: el proceso de limpieza y desinfección redujo la carga microbiana y materia orgánica de las superficies evaluadas, demostrada por los resultados obtenidos por el adenosina trifosfato y evaluación microbiológica, pero la inspección visual como herramienta única para evaluar la eficacia de la limpieza de las superficies, puede generar una falsa impresión de ambiente limpio.

Descriptores: Enfermería; Salas Quirúrgicas; Limpieza; Desinfección; Contaminación. 


\section{INTRODUCTION}

The optimization of processes related to the cleaning and disinfection (CD) of surfaces in healthcare environments is currently under discussion $^{(1)}$. Recent studies have shown that environmental contamination plays a significant role in the transmission of microorganisms (MOs) ${ }^{(1-2)}$.

Contaminated surfaces contribute to the endemic and/ or epidemic transmission of microbial pathogens that cause healthcare-associated infections (HAls), including Clostridium difficile, vancomycin-resistant enterococci (VRE), methicillinresistant Staphylococcus aureus (MRSA), Acinetobacter baumannii, Pseudomonas aeruginosa and norovirus. These HAl-causing MOs harbor an innate ability of long-term survival even on surfaces that have been subjected to CD processes ${ }^{(3-4)}$.

Furthermore, contaminated surfaces may act as a reservoir for these pathogens, which would allow their direct or indirect transmission to the patient ${ }^{(5)}$. Measures such as improving environmental CD quality and reducing pathogens spreading on surfaces can help preventing the spread of potentially pathogenic MOs, especially multidrugresistant strains. These measures, beneficial for both patients and healthcare professionals, thus play a vital role in the control of HAls ${ }^{(6-7)}$.

The likelihood of potentially pathogenic MOs proliferation and contamination that would affect vulnerable individuals and immunocompromised patients is increased by failure to adhere to good practices while assisting patients in healthcare settings, therefore affecting infection control ${ }^{(4)}$.

The surgical center (SC) is a high-risk area for pathogens transmission from team to patient as perioperative assistance involves frequent contact with the OR surfaces and dealing with the patient; hence, optimized $C D$ processes decrease the chances of pathogens transmission ${ }^{(8)}$. The challenges involved in the CD processes of the SC are the highest within the healthcare institution as keeping up with them involves combined actions withing the multi-professional team composed of nurses, anesthesiologists, surgeons and cleaning staff( ${ }^{(9)}$.

In order to confirm whether the CD processes are being carried out the way they should, monitoring methods should be implemented and would serve as a guide for determining the need for protocol adjustment and team training.

Currently, visual inspection and microbiological culture are the most commonly used methods to evaluate the quality of protocol used for the $C D$ of frequently touched surfaces in close proximity to patients. Although visual inspection is simple, inexpensive and easy to be performed, it does not access cleanliness objectively ${ }^{(10)}$.

In contrast, a microbiological culture can provide information about the presence of MOs on a surface; nevertheless, this method is more expensive and time-consuming and requires access to a microbiology laboratory. Consequently, routine bacteriological monitoring to assess the quality of environmental cleaning is not recommended ${ }^{(10)}$.

Adenosine triphosphate (ATP) bioluminescence assay, a rapidly implementable method with immediate feedback, has been used to assess the quality of surface cleaning. This method has enabled the instantaneous application of improvements in $C D$ protocol. However, each manufacturer has set a wide range of reference values, which has hindered the determination of a cut-off value to be used to identify a clean surface ${ }^{(11)}$.

\section{OBJECTIVES}

To evaluate different monitoring methods (visual inspection, ATP bioluminescence assay and microbiological analysis) for detecting the presence of organic or biological matter before and after $C D$ processes of the OR.

\section{METHODS}

\section{Ethical aspects}

The study was approved by the Ethics and Research Committee of the participating institution. The study development complied with national and international standards for research ethics.

\section{Design and period}

This cross-sectional study evaluated three CD monitoring methods - visual inspection, ATP bioluminescence assay and microbiological analysis - and was conducted in June 2018 at the surgical center of a large public hospital specializing in cardiac procedures. STROBE guidelines were used for data collection.

\section{Methodological procedures}

This study included a convenience sample comprising nine ORs. Sampling sites were defined according to the Association of periOperative Registered Nurses (AORN) description of frequently touched surfaces ${ }^{(9)}$. The following surfaces were sampled in each OR: upper tray of the anesthesia cart, upper third of the surgical table, keyboard of the drug infusion pump, side

table and electric scalpel keyboard. Samples were collected before and after CD using ATP bioluminescence assay ( 90 samples) and swab sampling for microbiological analysis ( 90 samples). All samples were submitted to the three methods of analysis using the same equipment, and all data collection was performed by the principal investigator.

Additionally, each area was submitted to visual inspection after the CD processes ( 45 comments). The samples were collected before and after the first surgery of the day in each OR.

For the visual inspection, an instrument was used to collect and record the following data: surgery identification, surgery start and end time, number of persons in the OR during the procedure, presence or absence of pressure on the team to hasten the theatre rotation, presence or absence of room temperature control, and the presence or absence of visible dirt to the investigator at the time of sampling. For this study, "dirt" was defined as the presence of blood, secretions or organic matter on a surface.

A portable luminometer and specific sampling swab were used for the bioluminescent detection of ATP. During sample collection, the investigator was wearing a surgical mask and procedural gloves after handwashing. Next, a swab was rotated and pressed horizontally and vertically to ensure contact with the entire surface within a polycarbonate area delimiter template $\left(10 \mathrm{~cm}^{2}\right)$ that had been sterilized in hydrogen peroxide.

Subsequently, the swab was returned to the packaging and gently shaken three times in both lateral directions at a $90^{\circ}$ angle, 
according to the manufacturer's recommendations. The swab was then inserted into the reading device in the upright position for the counting to start. Five seconds later, values were ready and expressed in relative luminescence units (RLUs).

For microbiological analysis, samples collected from the abovelisted sites were juxtaposed to the sampling areas submitted to ATP bioluminescence assay. The same aseptic care techniques were used. A total of 10 samples were collected before and after CD in each of the nine ORs, resulting at the end in 90 microbiological samples. For sample collection, sterile swabs were moistened with a sterile saline solution and smeared over the surface horizontally and vertically to ensure contact with the entire surface.

Next, the swab was inserted into a tube containing sterile culture medium (containing inorganic phosphates and balanced saline solution), to reduce the growth of bacteria and coliforms, and was sent to the microbiological analytical laboratory within 2 hours.

Subsequently, each swab was rolled on a Petri plate containing a non-specific blood agar medium that would allow the growth of any microorganism (Gram-positive or Gram-negative). These blood agar plates were incubated at $36 \pm 1^{\circ} \mathrm{C}$ for 48 hours, and readings were collected every 24 hours in triplicate.

To minimize the effects related to the Hawthorne effect, which relates to the professionals' attitude changing during observation ${ }^{(12)}$, different strategies were used during sampling including pauses in data collection and use of blank materials to sample other surfaces.

\section{Data analysis}

The collected data were submitted to a descriptive and inferential analysis conducted using the Statistical Package for the Social Sciences (SPSS), version 22 (IBM Corp., Armonk, New York, United States of America). Quantitative variables are expressed as means, medians, standard deviations, and minimum and maximum values.
Qualitative variables are expressed as absolute and relative frequencies. Comparison of samples collected before and after CD was made using the paired Student's t-test (parametric) or paired Wilcoxon test (nonparametric). The Spearman correlation coefficient was used to verify the relationship between quantitative variables. The Kruskal-Wallis test was used to compare more than two groups. The level of significance was set at $p=0.05$.

\section{RESULTS}

The sampling comprised 90 swab samples for ATP bioluminescence assay ( 45 pre-CD, 45 post-CD), 90 swab samples for microbiological analysis ( 45 pre-CD, 45 post-CD) and 45 visual inspections conducted post-CD. All cardiac procedures were classified as clean surgical procedures. An average of eight persons (range: 6-10) were in the OR during these procedures. A mean OR temperature of $19^{\circ} \mathrm{C}$ was recorded during surgical procedures requiring anesthesia. $C D$ processes were performed immediately after the patient left the OR in seven settings (77.7\%) but were delayed in two settings (22.3\%).

Regarding the visual inspection, 42 (93.3\%) of the assessed areas were considered clean. Only three (6.7\%) surfaces - electric scalpel, anesthesia cart and surgical table - had organic matter (blood) despite CD and were considered unacceptable.

Before CD processes, the lowest and highest levels of ATP were identified on the electrical scalpel (2,900 RLU) and the anesthesia cart $(5,524,605 \mathrm{RLU})$, respectively. After CD processes, the lowest and highest levels were detected on the side table (654 RLU) and electrical scalpel (133,851 RLU), respectively (Table 1).

An analysis of the ATP levels revealed a statistically significant reduction ( $p<0.0001$ ) before and after $C D$, with an average reduction of $92.6 \%$ (Table 2). Furthermore, all mean reductions in ATP levels per sampling site were statistically significant, with the greatest and smallest reductions observed on the anesthesia cart $(96.8 \%)$ and side table (74.1\%), respectively (Table 2 ).

Table 1 - Distribution of the different sampling sites according to their adenosine triphosphate (relative luminescence unit) levels Before and After cleaning and disinfection, São Paulo, São Paulo State, Brazil, 2018

\begin{tabular}{lcccc}
\hline \multirow{2}{*}{ Sampling Site } & \multicolumn{2}{c}{ Before Cleaning and Disinfection } & \multicolumn{2}{c}{ After Cleaning and Disinfection } \\
& Minimum - maximum & Mean $( \pm \text { SD })^{\S}$ & Minimum- maximum & Mean $( \pm$ SD) \\
\hline Electric scalpel & $2,900-1,424,979$ & $290,155.78( \pm 434,213.29)$ & $1,418-133,851$ & $40,075.44( \pm 42,223.17)$ \\
Infusion bomb & $13,900-216,540$ & $80,633.22( \pm 67,534.71)$ & $3,602-32,600$ & $15,314.22( \pm 10,526.53)$ \\
Anesthesia Cart & $7,580-5,524,605$ & $762,599.78( \pm 1,799,428.40)$ & $1,467-59,012$ & $24,772.44( \pm 16,296.69)$ \\
Side table & $3,443-142,157$ & $60,845.78( \pm 41,068.87)$ & $654-38,441$ & $15,742.67( \pm 13,083.18)$ \\
Surgery table & $6,511-2,938,237$ & $425,496.33( \pm 947,488.73)$ & $2,206-70,212$ & $24,553.22( \pm 25,312.19)$ \\
\hline
\end{tabular}

Note: ${ }^{5} S D$-Standard Deviation.

Table 2 - Distribution of differences before and after cleaning and disinfection according to sampling site and adenosine triphosphate levels (relative luminescence unit), São Paulo, São Paulo State, Brazil, 2018

\begin{tabular}{|lccccccc|}
\hline \multicolumn{1}{|c}{ Sampling Site } & Mean & $\mathbf{\pm S D ^ { \ddagger }}$ & Medium & Mimimum & Maximum & $\begin{array}{c}\text { \% of } \\
\text { reduction }\end{array}$ & $\boldsymbol{p}^{\S}$ \\
\hline Electric scalpel & $250,080.33$ & $426,068.95$ & $110,281.00$ & $1,482.00$ & $1,370,841.00$ & 86.20 & 0.008 \\
Infusion bomb & $65,319.00$ & $60,662.31$ & $41,805.00$ & $9,358.00$ & $190,291.00$ & 81.00 & 0.008 \\
Anesthesia Cart & $737,827.33$ & $1,797,429.84$ & $65,651.00$ & $6,308.00$ & $5,495,018.00$ & 96.80 & 0.015 \\
Side table & $45,103.11$ & $33,550.50$ & $41,561.00$ & $2,388.00$ & $106,886.00$ & 74.10 & 0.008 \\
Surgical table & $400,943.11$ & $930,327.64$ & $60,553.00$ & $3,027.00$ & $2,868,025.00$ & 94.20 & 0.008 \\
\hline
\end{tabular}

Note: ${ }^{*}$ SD - Standard Deviation; ${ }^{5}$ Wilcoxon Test. 
A statistically significant correlation $(p=0.029)$ was observed between the difference in ATP levels before and after CD and the visible presence of organic matter (visual inspection). There were no statistically significant differences between sampling sites with respect to the difference in ATP levels before and after $C D(p=0.479)$. Additionally, a weak but statistically significant correlation was observed between the ATP levels and surgery duration ( $r=0.309$; $\mathrm{p}=0.039$ ). However, no statistically significant correlation was observed between the ATP levels and the time spent on CD in the $\mathrm{OR}(\mathrm{r}=0.037 ; \mathrm{p}=0.807)$ or the number of persons present in the $\mathrm{OR}$ $(r=-0.111 ; p=0.466)$.

Table 3 shows that reduction in the numbers of MOs was observed on all surfaces after $C D$, particularly on the side table. The highest levels of MOs were detected on the anesthesia cart, followed by the side table. There was no statistically significant correlation between the reduction in the residual amount of MOs identified after $C D$ and the surgery duration $(r=0.063 ; p=0.683)$, the time spent on $C D(r=0.082$; $p=0.592)$, or the number of persons present in the OR $(r=0.292$; $p=0.052$ ). Similarly, there was no significant correlation between the number of colony-forming units (CFUs) detected after CD and the presence of visible organic matter (i.e., visual inspection) $(p=0.101)$.

As shown in Table 4, reduced numbers of CFUs of specific types of MOs were observed on the tested surfaces. Specifically, the CD processes eliminated $100 \%$ of the identified colonies of Micrococcus luteus/lylae, Rothia dentocariosa, Staphylococcus warneri, Aeromonas sobria, Staphylococcus aureus and Moraxella osloensis.

Table 3 - Number of microorganisms by colony-forming unit, São Paulo, São Paulo State, Brazil, 2018

\begin{tabular}{|c|c|c|c|c|c|c|c|}
\hline Sampling Site & $\begin{array}{l}\text { Microorganism } \\
\text { before/ after }\end{array}$ & $\begin{array}{l}\text { Mean } \\
\left(\text { CFU }^{+}\right)\end{array}$ & $\begin{array}{l} \pm \mathrm{SD}^{\ddagger} \\
\text { (CFU) }\end{array}$ & $\begin{array}{c}\text { Medium } \\
\text { (CFU) }\end{array}$ & $\begin{array}{l}\text { Min } \\
\text { (CFU) }\end{array}$ & Max (CFU) & $\%$ of reduction \\
\hline \multirow[t]{2}{*}{ Electric scalpel } & MO* before & 3.56 & 3.01 & 3.00 & 0 & 9 & \multirow{2}{*}{84.40} \\
\hline & MO after & 0.56 & 1.67 & 0.00 & 0 & 5 & \\
\hline \multirow[t]{2}{*}{ Infusion Bomb } & MO before & 3.78 & 3.93 & 3.00 & 0 & 10 & \multirow{2}{*}{70.60} \\
\hline & MO after & 1.11 & 1.96 & 0.00 & 0 & 5 & \\
\hline \multirow[t]{2}{*}{ Anesthesia Cart } & MO before & 11.44 & 18.21 & 4.00 & 0 & 54 & \multirow[b]{2}{*}{94.20} \\
\hline & MO after & 0.67 & 1.41 & 0.00 & 0 & 4 & \\
\hline \multirow[t]{2}{*}{ Side table } & MO before & 5.78 & 13.10 & 0.00 & 0 & 40 & \multirow{2}{*}{100.00} \\
\hline & MO after & 0.00 & 0.00 & 0.00 & 0 & 0 & \\
\hline \multirow[t]{2}{*}{ Surgical table } & MO before & 0.89 & 2.67 & 0.00 & 0 & 8 & \multirow{2}{*}{37.50} \\
\hline & MO after & 0.56 & 1.13 & 0.00 & 0 & 3 & \\
\hline \multirow[t]{2}{*}{ Total } & MO before & 5.09 & 10.49 & 1.00 & 0 & 54 & \multirow{2}{*}{88.70} \\
\hline & MO after & 0.58 & 1.39 & 0.00 & 0 & 5 & \\
\hline
\end{tabular}

Note: ${ }^{*} \mathrm{MO}$ - microorganism; ${ }^{+} \mathrm{CFU}$ - colony-forming unit; ${ }^{\ddagger} \mathrm{SD}$ - Standard Deviation.

Table 4 - Average percentage of colony-forming units'reduction after cleaning and disinfection per identified microorganisms, São Paulo, São Paulo State, Brazil, 2018

\begin{tabular}{|c|c|c|c|c|c|c|c|c|}
\hline Microorganisms & & Mean & Medium & SD $^{*}$ & $\operatorname{Min}^{+}$ & $\operatorname{Max}^{\ddagger}$ & $\%$ reduction & $p^{\S}$ \\
\hline Staphylococcus hominis ssp & $\begin{array}{l}\text { Before } \\
\text { After }\end{array}$ & $\begin{array}{l}0.18 \\
0.00\end{array}$ & $\begin{array}{l}0.00 \\
0.00\end{array}$ & $\begin{array}{l}0.78 \\
0.00\end{array}$ & $\begin{array}{l}0 \\
0\end{array}$ & $\begin{array}{l}5 \\
0\end{array}$ & 100.00 & 0.059 \\
\hline Micrococcus /uteus/lylae & $\begin{array}{l}\text { Before } \\
\text { After }\end{array}$ & $\begin{array}{l}1.07 \\
0.00\end{array}$ & $\begin{array}{l}0.00 \\
0.00\end{array}$ & $\begin{array}{l}2.07 \\
0.00\end{array}$ & $\begin{array}{l}0 \\
0\end{array}$ & $\begin{array}{c}10 \\
0\end{array}$ & 100.00 & 0.001 \\
\hline Staphylococcus haemolyticus & $\begin{array}{l}\text { Before } \\
\text { After }\end{array}$ & $\begin{array}{l}0.67 \\
0.13\end{array}$ & $\begin{array}{l}0.00 \\
0.00\end{array}$ & $\begin{array}{l}2.90 \\
0.55\end{array}$ & $\begin{array}{l}0 \\
0\end{array}$ & $\begin{array}{c}18 \\
3\end{array}$ & 80.00 & 0.352 \\
\hline Aerococcus viridans & $\begin{array}{l}\text { Before } \\
\text { After }\end{array}$ & $\begin{array}{l}0.00 \\
0.02\end{array}$ & $\begin{array}{l}0.00 \\
0.00\end{array}$ & $\begin{array}{l}0.00 \\
0.15\end{array}$ & $\begin{array}{l}0 \\
0\end{array}$ & $\begin{array}{l}0 \\
1\end{array}$ & --- & 0.317 \\
\hline Rothia dentocariosa & $\begin{array}{l}\text { Before } \\
\text { After }\end{array}$ & $\begin{array}{l}0.04 \\
0.00\end{array}$ & $\begin{array}{l}0.00 \\
0.00\end{array}$ & $\begin{array}{l}0.30 \\
0.00\end{array}$ & $\begin{array}{l}0 \\
0\end{array}$ & $\begin{array}{l}2 \\
0\end{array}$ & 100.00 & 0.317 \\
\hline Staphylococcus saprophyticus & $\begin{array}{l}\text { Before } \\
\text { After }\end{array}$ & $\begin{array}{l}0.00 \\
0.04\end{array}$ & $\begin{array}{l}0.00 \\
0.00\end{array}$ & $\begin{array}{l}0.00 \\
0.30\end{array}$ & $\begin{array}{l}0 \\
0\end{array}$ & $\begin{array}{l}0 \\
2\end{array}$ & --- & 0.317 \\
\hline Staphylococcus cohnii ssp & $\begin{array}{l}\text { Before } \\
\text { After }\end{array}$ & $\begin{array}{l}0.00 \\
0.04\end{array}$ & $\begin{array}{l}0.00 \\
0.00\end{array}$ & $\begin{array}{l}0.00 \\
0.30\end{array}$ & $\begin{array}{l}0 \\
0\end{array}$ & $\begin{array}{l}0 \\
2\end{array}$ & --- & 0.317 \\
\hline Staphylococcus epidermidis & $\begin{array}{l}\text { Before } \\
\text { After }\end{array}$ & $\begin{array}{l}0.51 \\
0.04\end{array}$ & $\begin{array}{l}0.00 \\
0.00\end{array}$ & $\begin{array}{l}1.63 \\
0.30\end{array}$ & $\begin{array}{l}0 \\
0\end{array}$ & $\begin{array}{l}8 \\
2\end{array}$ & 91.30 & 0.058 \\
\hline Achromobacter xylosoxidans/denitrificans & $\begin{array}{l}\text { Before } \\
\text { After }\end{array}$ & $\begin{array}{l}0.33 \\
0.20\end{array}$ & $\begin{array}{l}0.00 \\
0.00\end{array}$ & $\begin{array}{l}1.65 \\
0.94\end{array}$ & $\begin{array}{l}0 \\
0\end{array}$ & $\begin{array}{c}10 \\
5\end{array}$ & 40.00 & 0.581 \\
\hline Staphylococcus warneri & $\begin{array}{l}\text { Before } \\
\text { After }\end{array}$ & $\begin{array}{l}0.04 \\
0.00\end{array}$ & $\begin{array}{l}0.00 \\
0.00\end{array}$ & $\begin{array}{l}0.30 \\
0.00\end{array}$ & $\begin{array}{l}0 \\
0\end{array}$ & $\begin{array}{l}2 \\
0\end{array}$ & 100.00 & 0.317 \\
\hline Staphylococcus capitis & $\begin{array}{l}\text { Before } \\
\text { After }\end{array}$ & $\begin{array}{l}0.78 \\
0.09\end{array}$ & $\begin{array}{l}0.00 \\
0.00\end{array}$ & $\begin{array}{l}5.22 \\
0.60\end{array}$ & $\begin{array}{l}0 \\
0\end{array}$ & $\begin{array}{c}35 \\
4\end{array}$ & 88.60 & 0.655 \\
\hline Aeromonas sobria & $\begin{array}{l}\text { Before } \\
\text { After }\end{array}$ & $\begin{array}{l}0.42 \\
0.00\end{array}$ & $\begin{array}{l}0.00 \\
0.00\end{array}$ & $\begin{array}{l}2.83 \\
0.00\end{array}$ & $\begin{array}{l}0 \\
0\end{array}$ & $\begin{array}{c}19 \\
0\end{array}$ & 100.00 & 0.317 \\
\hline Staphylococcus aureus & $\begin{array}{l}\text { Before } \\
\text { After }\end{array}$ & $\begin{array}{l}0.89 \\
0.00\end{array}$ & $\begin{array}{l}0.00 \\
0.00\end{array}$ & $\begin{array}{l}5.96 \\
0.00\end{array}$ & $\begin{array}{l}0 \\
0\end{array}$ & $\begin{array}{c}40 \\
0\end{array}$ & 100.00 & 0.317 \\
\hline Moxarella osloensis & $\begin{array}{l}\text { Before } \\
\text { After }\end{array}$ & $\begin{array}{l}0.16 \\
0.00\end{array}$ & $\begin{array}{l}0.00 \\
0.00\end{array}$ & $\begin{array}{l}0.74 \\
0.00\end{array}$ & $\begin{array}{l}0 \\
0\end{array}$ & $\begin{array}{l}4 \\
0\end{array}$ & 100.00 & 0.180 \\
\hline
\end{tabular}




\section{DISCUSSION}

These methods that were used in this study evaluate three distinct analytes that contribute to the quality of surface CD, namely a reduction in the amount of organic matter (ATP levels), microbiological pathogens (microbiological cultures) and visual dirt (visual inspection, the most commonly used method in the majority of healthcare institutions).

Interestingly, although $93.3 \%$ of the areas inspected visually in this study seemed to be clean, high levels of ATP and presence of MOs relevant to biofilm formation were detected ${ }^{(13-14)}$. These data demonstrate that visual inspection alone is a poor indicator of the quality of surface $C D$.

A similar previous study assessed the cleaning of eight ORs using visual inspection, aerobic culture (recognized by the authors as the gold standard) and ATP bioluminescence assay for 12 frequently touched surfaces (85 total samples). These methods revealed inadequate $C D$ processes in $11.8 \%, 20.0 \%$ and $50.6 \%$ of sites assessed before cleaning and $4.7 \%, 5.9 \%$, and $21.2 \%$ sites assessed after cleaning, respectively. The authors of the previous study concluded that ATP bioluminescence assay was more sensitive than visual inspection (63.6\% vs. $27.3 \%)$ and classified it as a rapid and useful method for evaluating the quality of cleaning protocols and monitoring environmental cleanliness in hospitals ${ }^{(14)}$.

In this study, the manufacturer of the equipment used for the ATP bioluminescence assay did not set a cut-off value. Therefore, it was decided to assess the mean reduction in ATP levels, ranging between $74.1 \%$ and $96.8 \%$, and then was decided a mean post-CD percentage reduction parameter of $92.6 \%$. Set cut-off values for these new methods of CD quality assessment as well as microbiological safety of an environment (e.g., ATP levels) are needed to convey the meaning of these values in terms of risks to patients and professionals who come into contact with potentially contaminated surfaces. As stated previously, different devices and technologies with the same purpose are, however, commercialized but do not determine cut-off values. Additionally, these devices could potentially be used to assess a wide range of surfaces and different loads of organic matter. These features increase the difficulty of setting standard cut-off values.

In an OR, the microbiota usually comprises MOs such as Staphylococcus spp., Enterobacter spp., Micrococcus spp., Acinetobacter spp., Klebsiella spp., Brevibacterium spp., and Pseudomonas spp ${ }^{(15)}$. In the present study, Staphylococcus aureus and Staphylococcus epidermidis were identified in the ORs assessed areas. These common causative agents of HAls are particularly associated with devices such as vascular catheters, prosthetics and artificial heart valves due to their ability to adhere to the smooth material surface and thus facilitate the formation of biofilm ${ }^{(15)}$.

It is important to mention that an urgent need for reinforcement of and attention to cleaning and disinfection measures was generated $^{(16-17)}$ with the advent of the new Coronavirus (SARS-CoV-2) and that's because of its stability in aerosols and surfaces - which allows its transmission by fomites - and its estimated prolonged survival on surfaces such as stainless steel (3 days), plastic (3 days), cardboard (1 day) and copper (4 hours).

It is important as well to point out a recent study that analyzed several surfaces of an Intensive Care Unit (ICU) and found that more than $90 \%$ of the assessed areas had multi-resistant MOs such as $\mathrm{S}$. aureus in biofilms form, even after final cleaning with neutral detergent and hypochlorite ${ }^{(14)}$.

Currently, significant levels of contamination are being found in hospital environments and the used CD protocols are often inadequate to control the formation of biofilms. For example, MOs such as Staphylococcus aureus can remain viable for long periods within biofilms present on dry surfaces and are thus protected from physical removal and chemical disinfection ${ }^{(15)}$. Moreover, given the ability of most nosocomial pathogens to persist on inanimate surfaces for weeks or months, disinfection of the areas of care is recommended for manually touched patients as these areas can serve as vectors for the cross-transmission of microorganisms such as Escherichia coli, Salmonella spp. and Staphylococcus aureus. Adequate disinfection can reduce the transmission risk of these nosocomial pathogens from inanimate surfaces to vulnerable patients ${ }^{(13)}$.

Therefore, and in an attempt to minimize the transmission of pathogens, intensifying routine cleaning as well as the adequacy of time, frequency and specific care in cleaning surfaces deserve greater attention since the removal of dirt is relevant to the reduction of biofilm ${ }^{(14)}$.

Our findings in this study and the previous literature highlight the importance of intensifying routine $C D$ protocols to minimize the spread of pathogens. Furthermore, our findings highlight the importance of using adequate duration of time and level of attention as well as the importance of frequency when it comes to surfaces' cleaning since the removal of organic matter is relevant to the reduction of biofilm formation.

Therefore, improvement and emphasizing in these areas appear to be fundamental for the development of multi-professional team and would be expected to have direct effects on the quality and safety of care provided to the patient ${ }^{(15)}$.

\section{Study limitations}

A limitation of the present study was related to the teams' concerns about the performance assessment leading to changes such as an increase in the duration of OR cleaning. In this study, the average duration of cleaning between surgeries (from patient exit until readiness for the next patient) was 55 minutes.

\section{Contributions to nursing, health or public policy}

The results of this study are expected to contribute to perioperative nursing procedures. These findings will better enable nurses to select the ideal method for evaluating the $C D$ of surfaces in the OR. Specifically, nursing teams will be equipped to select the most appropriate and realistic process for use in their environment and thus improve the quality and safety of surgical patient care.

\section{CONCLUSIONS}

According to the present study, a visual inspection would identify only $6.7 \%$ of assessed areas as inadequately cleaned. By contrast, the ATP bioluminescence assay detected high levels of 
organic matter, even on surfaces subjected to CD protocols, while the microbiological analysis detected the presence of pathogens relevant to the incidence of HAls, although statistically significant reduction in these MOs levels was observed after $C D$. To date, few reports have proposed acceptable cut-off values for these analyses that could be used to determine the safety of an OR. In this regard, the present study observed that a decrease of more than $74 \%$ in assay values after CD was statistically significant. However, more studies to compare different surfaces and tools used for the same purpose (i.e., ATP bioluminescence) are necessary to set parameters for safe patient care in SC. Finally, the present study highlights the importance of proper CD within healthcare institutions and demonstrates how visual inspection of surface $C D$ can lead to a false impression of environmental cleanliness and safety.

\section{FUNDING}

This project was financed by the Coordination for the Improvement of Higher Education Personnel - CAPES 001.

\section{REFERENCES}

1. Dancer SJ. Controlling hospital-acquired infection: focus on the role of the environment and new technologies for decontamination. Clin Microbiol Rev. 2014;27(4):665-90. https://doi.org/10.1128/CMR.00020-14

2. Weber DJ, Kanamori H, Rutala WA. No touch technologies for environmental decontamination: focus on ultraviolet devices and hydrogen peroxide systems. Curr Op Infect Dis. 2016;29(4):424-49. https://doi.org/10.1097/QCO.0000000000000284

3. Centers for Disease Control. Guidelines for Environmental Infection Control in Health-Care Facilities [Internet]. Atlanta: CDC; 2017 [cited 2020 Dec 01]. Available from: https://www.cdc.gov/infectioncontrol/pdf/guidelines/environmental-guidelines.pdf

4. Weber DJ, Rutala WA, Anderson DJ, Chen LF, Sickbert-Bennett EE, Boyce JM. Effectiveness of ultraviolet devices and hydrogen peroxide systems for terminal room decontamination: Focus on Clinical trials. Am J Infect Control. 2016;44(5):E77-E84. https://doi.org/10.1016/j. ajic.2015.11.015

5. Han JH, Sullivan N, Leas BF, Pegues DA, Kaczmarek JL, Umscheid CA. Cleaning hospital room surfaces to prevent health care-associated infections: a technical brief. Ann Intern Med. 2015;163(8):598-607. https://doi.org/10.7326/M15-1192

6. Association of Perioperative Registered Nurses. Guidelines for perioperative practice. Denver: AORN [Internet]. 2017[cited 2020 Dec 01]. Available from: https://www.aorn.org/guidelines/clinical-resources/aorn-standards

7. Boyce JM. Modern technologies for improving cleaning and disinfection of environmental surfaces in hospitals. Antimicrob Resist Infect Control [Internet]. 2016[cited 2020 Dec 01];5:10. Available from: https://aricjournal.biomedcentral.com/articles/10.1186/s13756-016-0111-x

8. Spruce L. Thorough environmental cleaning helps to prevent pathogen transmission. AORN J. 2020;111(6):708-09. https://doi:10.1002/ aorn.13056

9. Spruce L. Back to Basics: environmental cleaning hazards. AORN J. 2017;106(5):424-32. https://doi.org/10.1016/j.aorn.2017.08.013

10. World Health Organization (WHO). Global Guidelines for the prevention of surgical site Infection [Internet]. Geneva: WHO; 2017[cited 2020 Dec 01]. Available from: https://www.who.int/gpsc/ssi-guidelines/en/

11. Huang YS, Chen YC, Chen ML, et al. Comparing visual inspection, aerobic colony counts, and adenosine triphosphate bioluminescence assay for evaluating surface cleanliness at a medical center. Am J Infect Control [Internet]. 2015[cited 2020 Dec 01];43(8):882-886. Available from: https://www.ncbi.nlm.nih.gov/pubmed/25952617\#

12. Muldoon J. Spontaneity Is the Spice of Management: Elton Mayo's Hunt for Cooperation. The Palgrave Handbook of Management History [Internet]. 2020[cited 2020 Dec 01]. 545-54. Available from: https://doi.org/10.1007/978-3-319-62114-2_29

13. Rutala AW, Weber DJ, Monitoring and improving the effectiveness of surface cleaning and disinfection. Am J Infect Control. 2016;44(5):e69-e76. https://doi.org/10.1016/j.ajic.2015.10.039

14. Hu H, Johani K, Gosbell IB. Intensive care unit environmental surfaces are contaminated by multidrug-resistant bacteria in biofilms: combined results of conventional culture, pyrosequencing, scanning electron microscopy, and confocal laser microscopy. J Hosp Infect [Internet]. 2015[cited 2020 Dec 01];91(1):35-44 Available from: https://www.ncbi.nlm.nih.gov/pubmed/26187533\#

15. Ledwoch K, Dancer SJ, Otter JA, Kerr K, Roposte K. Beware biofilm! Dry biofilms containing bacterial pathogens on multiple healthcare surfaces; a multi-center study. J Hosp Infect. 2018;100(3):e47-59. https://doi.org/10.1016/j.jhin.2018.06.028

16. Stokes EK, Zambrano LD, Anderson KN. Coronavirus Disease 2019 Case Surveillance - United States. MMWR Morb Mortal Wkly Rep. 2020;69:759-65. https://doi.org/10.15585/mmwr.mm6924e2external

17. Van Doremalen N, Bushmaker T, Morris DH, Holbrook MG, Gamble A, Williamson BN, et al. Aerosol and surface stability of SARS-CoV-2 as compared with SARS-CoV-1. N Engl J Med. 2020;382(16):1564-7. https://doi.org/10.1056/NEJMc2004973 